\title{
Biosynthesis of macromolecular and lipid classes by phytoplankton in the Northeast Water Polynya
}

\author{
R. E. H. Smith ${ }^{1, *}$, M. Gosselin ${ }^{2}$, G. Kattner ${ }^{3}$, L. Legendre ${ }^{4}$, S. Pesant ${ }^{4}$ \\ ${ }^{1}$ Department of Biology, University of Waterloo, Waterloo, Ontario, Canada N2L 3G1 \\ ${ }^{2}$ Département d'océanographie, Université du Québec à Rimouski, 310 Allée des Ursulines, Rimouski, \\ Québec, Canada G5L 3A1
}

${ }^{3}$ Alfred Wegener Institut für Polar und Meeresforschung, Postfach 120161, D-27515 Bremerhaven, Germany

${ }^{4}$ GIROQ, Département de biologie, Université Laval, Ste-Foy, Québec, Canada G1K 7 P4

\begin{abstract}
The patterns and environmental correlates of macromolecular synthesis were investigated during 1993 in the Northeast Water Polynya, a region of variable ice cover and hydrodynamic regime on the continental shelf of northeast Greenland $\left(77^{\circ}\right.$ to $\left.81^{\circ} \mathrm{N}\right)$. Allocation of photosynthate to major macromolecular classes (protein, lipid, and polysaccharides), like phytoplankton biomass and primary production, showed strong spatio-temporal variability. Time series observations in the central part of the polynya and correlational analysis over all stations provided physiological evidence of nutrient deficiency in surface populations as nitrate and silicate were depleted. Lipid, rather than polysaccharide, synthesis was favoured as nutrient concentrations decreased, and $\mathrm{C} / \mathrm{N}$ assimilation ratios inferred from protein labelling reached very high values ( $>15$ by weight). $\mathrm{C} / \mathrm{N}$ composition ratios increased in parallel but remained lower $(<10)$ than the assimilation ratios. Lipid synthesis shifted towards neutral lipids and glycolipids, and away from phospholipids, as nutrient concentrations declined to their observed minimum. At stations with a dominance of large (mainly diatom) phytoplankton more of the lipid synthesis was directed to glycolipids and less to phospholipids and neutral lipids than at those dominated by small (mainly flagellate) phytoplankton, but relative allocation to total lipids and other macromolecular classes was not significantly different between the 2 types of stations. Although both nitrate and silicate became depleted, changes in silicate were most closely related to the physiological changes observed, consistent with a predominance of diatoms at the more productive stations.
\end{abstract}

KEY WORDS: Proteins - Lipids Polysaccharides Primary production - Bıosynthesis - Polynya

\section{INTRODUCTION}

The biochemical composition and biosynthetic patterns of phytoplankton can provide valuable clues to the environmental factors that regulate primary production (Morris 1981), and are also of significance to the cycling and trophic transfer of photosynthetically fixed carbon in the marine food web (e.g. Laws 1991, Parrish et al. 1995). Actively growing phytoplankton with an abundant supply of inorganic nutrients generally synthesize mainly protein and lesser amounts of storage compounds such as neutral lipids, carbohydrates and low molecular weight metabolites (Morris

•E-mail: rsmith@biology.watstar.uwaterloo.ca
1981, Laws 1991). Various indices, based mainly on the relationship of protein to putative storage compounds or classes, have been applied in various settings to characterize changes in physiology and growth rates associated with growth-limiting conditions of light and/or nutrient supply (e.g. Morris 1981, DiTullio \& Laws 1983, 1986, Smith \& Geider 1985, Smith et al. 1987, Madariaga \& Fernández 1990, Madariaga et al. 1991. Madariaga \& Joint 1992). Indices based on biosynthesis rates, as inferred from photosynthate allocation, have the advantage of minimizing interference from non-algal components of the seston but are nonetheless influenced not only by a variety of abiotic factors but also by species succession and taxonomic composition of the phytoplankton (e.g. Rivkin 1985, 
Fernández et al. 1992, Madariaga 1992) and by the analytical methods employed (Hitchcock 1983, Wainmann \& Lean 1994). Understanding of the information inherent in physiological signals such as biosynthetic patterns can therefore benefit from additional field studies in varying oceanographic conditions and phytoplankton communities. The same is true of efforts to develop models for predicting the synthesis of macromolecular classes of particular interest, such as lipids (e.g. Wainmann \& Lean 1992) and protein (Lean et al. 1989). The expedition of RV 'Polarstern' to the Northeast Water in 1993 afforded an opportunity to study biosynthetic patterns of polar marine phytoplankton in a hydrodynamically complex system.

The Northeast Water (NEW) is a region within the Greenland Sea, extending approximately from $77^{\circ}$ to $81^{\circ} \mathrm{N}$ on the North East Greenland Shelf, at the southern limit of the permanent Arctic ice pack. A polynya (a recurring mesoscale area of reduced ice cover) opens annually between April and September (Schneider \& Budéus 1994, 1995) so that, within the NEW, the conditions range from open to fully ice-covered waters during the spring and summer months. Primary production and plankton biomass can be high, but are characterized by strong spatio-temporal variability (Lara et al. 1994, Smith 1995). The light regime, as influenced by ice cover and mixing depth, and the nutrient regime are both implicated in the control of primary production in the NEW (Smith 1995). Depletion of nitrate-nitrogen and elevated ratios of $C: N$ assimilation and composition suggest that nitrogen is a key factor in limiting primary production (Lara et al. 1994, Smith 1995). Silicate (i.e. ortho-silicic acid) is also depleted at sites of intense phytoplankton development and may be of significance to the control of export production of the larger, primarily diatom-dominated, phytoplankton (Dugdale et al. 1995, Pesant et al. 1996). One of the major objectives of the current work was to assess the physiological nutrient status of phytoplankton in the NEW and the relative importance of silicon versus nitrogen limitation.

Of the various macromolecular classes, lipids are of special interest for their nutritional importance to consumers and potential for contaminant transfer (Kattner et al. 1989, Wainmann \& Lean 1992, Parrish et al. 1995). Nutrients and taxonomic affiliation both influence the proportion of fixed carbon that phytoplankton direct to lipids (Shifrin \& Chisholm 1981, Madariaga 1992, Fernández et al. 1994a) and there has been some success in predicting lipid biosynthesis from environmental factors in freshwater phytoplankton communities (Wainmann \& Lean 1992). The total lipid pool comprises several functionally distinct classes of compound (Gurr \& Harwood 1991) and previous work with natural marine phytoplankton has shown that changing allocation to different classes underlies variations in total lipid concentration (Parrish 1987) and synthesis (Smith \& D'Souza 1993). The neutral lipid class is of special interest as a potentially specific indicator of nutrient stress. In the current work, we partitioned total lipid synthesis into neutral lipids (storage-related), glycolipids (largely pigments and photosynthetic membrane components) and phospholipids (mainly other membrane components) in hope of better resolving the physiological status of the phytoplankton and the factors controlling total lipid synthesis

\section{MATERIALS AND METHODS}

Study area and sampling methods. A total of 170 stations in the NEW were occupied for phytoplankton sampling from May 23 to July 31, 1993 (RV 'Polarstern' cruises ARK IX/2 and 3) as described more fully in Pesant et al. (1996). We deal here mainly with a subset of 22 stations at which photosynthate allocation was measured (see Figs. I \& 2 for iocations). The greatest concentration of our subset of stations was in the central part of the polynya region, in and near the Norske and Westwind Troughs (Schneider \& Budéus 1994). Repeated visits to the area between $80^{\circ}$ and $81^{\circ} \mathrm{N}$ and between $11^{\circ}$ and $14^{\circ} \mathrm{W}$ (see Fig. 1) provided information on the time series of events in the central part of the polynya. Of the 22 stations, 6 had ice concentrations $>80 \%$ while 12 had ice concentrations $<10 \%$, with the remaining 6 intermediate, according to observations from deck. Photosynthetically active radiation (PAR, 400 to $700 \mathrm{~nm}$ ) was recorded on deck at $30 \mathrm{~min}$ intervals using a LI-COR 190 SA quantum meter.

At each station, water was sampled using a rosette sampler package that included a Seabird $911+$ CTD profiler, a LI-COR 185B underwater quantum PAR meter and twelve 12 l Niskin bottles (retrofitted with silicon springs to eliminate problems of toxicity associated with rubber springs). Samples were taken at 11 depths but we deal here mainly with those from the 100,5 and $0.1 \%$ optical depths at which biosynthesis was measured. Subsamples were immediately withdrawn from the Niskin bottles to determine nutrients and estimate phytoplankton variables, which included particulate organic carbon and nitrogen (POC and PON), photosynthetic pigments, phytoplankton identification, and primary production and biosynthetic rates.

Analytical procedures. Dissolved inorganic nutrients (nitrate, nitrite, ammonium, phosphate and silicate) were determined aboard ship with a Technicon Autoanalyzer (Kattner \& Becker 1991) and POC and PON retained on pre-combusted GF/F glass fiber fil- 
ters were determined with a Perkin-Elmer CHN analyzer. Chlorophyll a (chl a) was determined using a Turner model 112 fluorometer after $24 \mathrm{~h}$ extraction in $90 \%$ acetone at $5^{\circ} \mathrm{C}$ without grinding (Parsons et al. 1984), using GF/F filters for total chl $a$ and polycarbonate membranes of nominal $5 \mu \mathrm{m}$ pore size for size fractionation (Pesant et al. 1996). Phytoplankton identification was performed on samples preserved with acid Lugol's solution.

Primary production methods are fully described in Pesant et al. (1996). We used the ${ }^{14} \mathrm{C}$ uptake protocol (Parsons et al. 1984) and deck incubation procedures which simulated an irradiance appropriate to the original optical depth of the samples, using blue plastic filters to improve the spectral simulation for the deeper (<15\%) optical depths. Temperature was regulated by circulating surface seawater through the deck incubators. Incubations were $24 \mathrm{~h}$ long and were terminated by filtration on GF/F filters, with additional size fractionation using $5 \mathrm{\mu m}$ pore size polycarbonate membranes. We routinely used duplicate light bottles and a single dark bottle at each optical depth but, for biosynthesis measurements, a third replicate light bottle was included. Unless otherwise noted, the values for photosynthate allocation at each station and optical depth are the means for the triplicate bottles. All values were corrected for assimilation that occurred in the dark bottle. The activity incorporated was determined onboard using a Packard Scintillation Counter 19TR.

Samples for determining biosynthesis (photosynthate allocation) were collected in parallel with the main primary production series and the samples (on $\mathrm{GF} / \mathrm{F}$ filters) were stored frozen pending analysis after the cruise. Allocation to macromolecular classes was determined using a variation of the Li et al. (1980) method, as previously applied in the North Atlantic (Smith \& D'Souza 1993). In brief, the filters were first extracted in $2: 1$ chloroform:methanol at $-20^{\circ} \mathrm{C}$ and the extract filtered through a GF/F filter. The filtrate was mixed throughly $2: 1$ with $0.88 \% \mathrm{KCl}$, then centrifuged to separate 2 phases. The chloroform phase contains the lipids while the alcohol-water phase contains low molecular weight metabolites (LMW). The chloroformmethanol insoluble material was then extracted in $5 \%$ trichloroacetic acid (TCA) at $80^{\circ} \mathrm{C}$. The TCA-soluble material in the filtrate is termed polysaccharide, while the insoluble residue on the filter is protein. Each class (lipid, LMW, polysaccharide and protein) was assayed using a liquid scintillation counter. For the lipids, a subsample of the extract was assayed to determine total lipid and the rest was carried on to the lipid class determinations. The total of the macromolecular classes was always $>84 \%$ of the total assimilation as measured by direct scintillation counting of parallel GF/F filters. The coefficient of variation (standard deviation/mean) for triplicate determinations provided a measure of the combined analytical and experimental (inter-bottle) error, and averaged 22.6, 10.5, 11.6 and $24.9 \%$ for LMW, protein, polysaccharide and lipid respectively.

Allocation of photosynthate among lipid classes was determined using the method described by Smith \& D'Souza (1993). In brief, chloroform lipid extracts were loaded on pre-packed silica gel columns (Sep-Pak, Waters Associates, Milford, MA, USA) and eluted with a sequence of 6 solvent phases of increasing polarity. The solvent phases were chloroform $+1 \%$ ethanol 1:1 chloroformacetone, pure acetone, $2: 1$ chloroform methanol, 1:1 chloroform:methanol, and pure methanol. The first phase contains neutral lipids. The next 2 phases comprise the 'acetone-mobile' lipids (mainly photosynthetic pigments and glycolipids; Parrish 1987). The chloroform phases contain mainly phospholipids and some free fatty acids. The final, methanol, phase is expected to contain only low molecular weight degradation products and was never more than $2 \%$ of the total label recovered. Recovery was never less than $90 \%$ of the total lipid. The 6 phases were collected, dried, and assayed with a liquid scintillation counter. The counts for the 2 acetone phases were pooled in subsequent analysis, as were the counts for the 2 chloroform phases. The pooled results were termed glycolipids and phospholipids respectively, reflecting the dominant type of material expected in each class. The coefficient of variation for triplicate determinations averaged 14.5, 6.2 and $15.1 \%$ for neutral lipids, glycolipids and phospholipids respectively.

Data analysis. The spatio-temporal variability of conditions in the NEW was analyzed by Pesant et al. (1996) in terms of 3 major regimes of phytoplankton size distribution and productivity (Legendre \& Le Fèvre 1991). Regimes 1 and 2 corresponded essentially to stations with a dominance of large (mainly diatom) phytoplankton. Regime 1 represents developing bloom conditions in mostly open water with stable surface stratification and relatively plentiful nutrients, while Regime 2 represents a later stage of development in which depletion of surface nutrients is significant and large cells are sinking to the relatively deep pycnocline, where they tend to accumulate. Regime 5 (Regimes 3 and 4 were not represented in the NEW in 1993) corresponds to waters with a high degree of ice cover, weak stratification, plentiful nutrients and relatively low primary production with a dominance of small (mostly flagellate) phytoplankton. The sorting of stations by regime in this fashion is very useful because the complex spatio-temporal variability in the NEW makes it difficult to meaningfully categorize the stations with respect to hydrographic domain, hydrodynamic conditions or ice cover. The biosynthetic pat- 

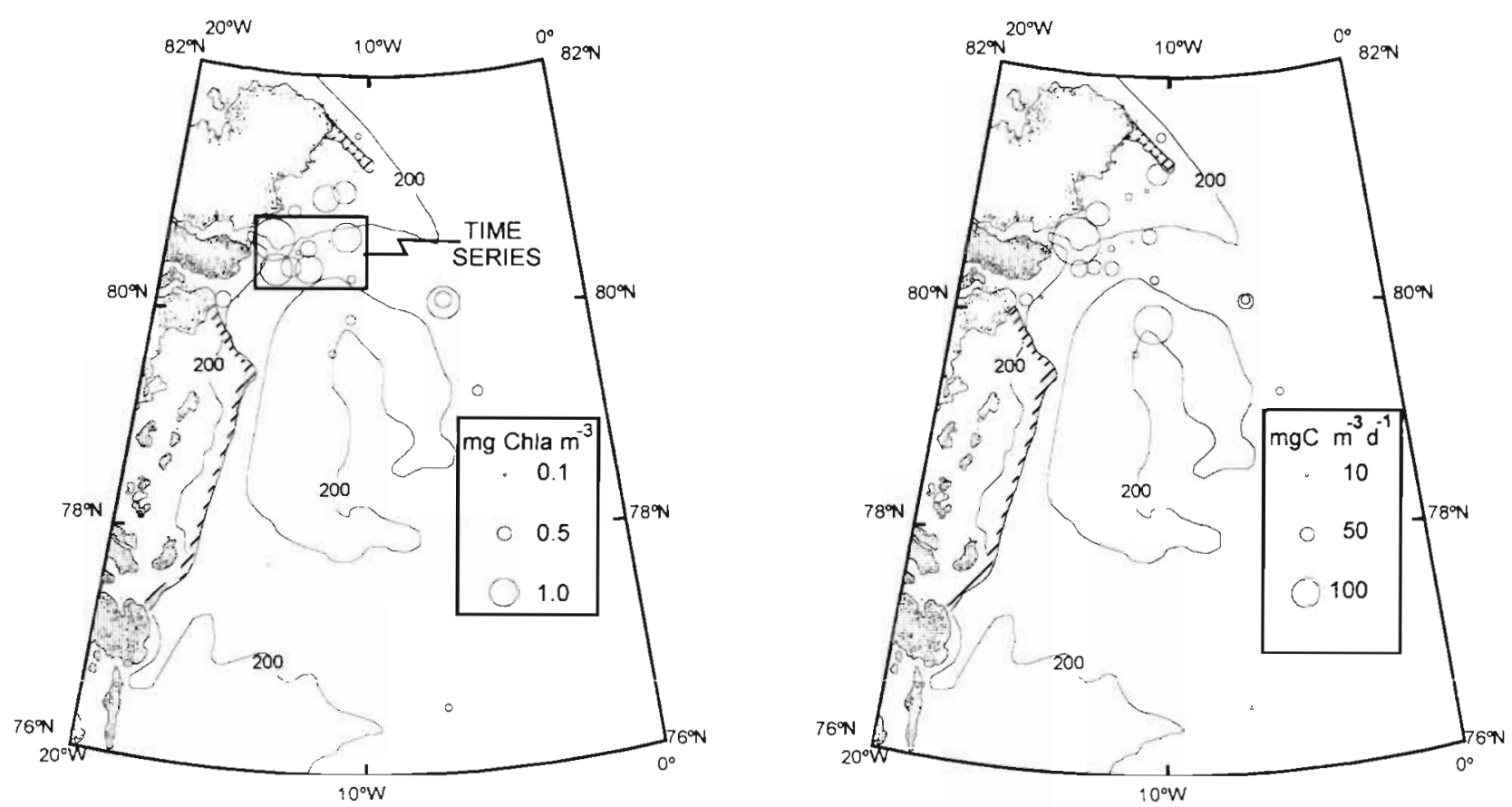

Fig. 1. Chl a concentration ( $\mathrm{mg} \mathrm{chl} \mathrm{a} \mathrm{m}^{-3}$ ) and primary production rates ( $\mathrm{mg} \mathrm{C} \mathrm{m}^{-3} \mathrm{~d}^{-1}$ ) in surface samples in and near the Northeast Water Polynya in summer 1993 . The $200 \mathrm{~m}$ isobath is shown

terns for our subset of stations were analyzed by regime as one approach to elucidating the effects of phytoplankton community composition and associated environmental conditions

We also used correlation and regression analyses (Draper \& Smith 1966) to determine the best linear relationships between allocation to macromolecular and lipid classes and both environmental variables (temperature, ice cover, major nutrients and irradiance) and biotic variables (chl a concentration and total primary production rate). Daylength, an important correlate of macromolecular synthesis in some other systems (Cuhel \& Lean 1987. Wainmann \& Lean 1992), was nominally 24 h throughout the observation period and was treated as a constant.

Macromolecular allocation patterns can be used to infer the $\mathrm{C} / \mathrm{N}$ assimilation ratio of phytoplankton on the assumption that protein is the principal intracellular reservoir of nitrogen (DiTullio \& Laws 1983, 1986 , Laws 1991). We calculated the $C / N$ assimilation ratio from the observed allocation to protein assuming that protein $\mathrm{N}$ accounted for $85 \%$ of cellular $\mathrm{N}$, with protein having a $\mathrm{N} / \mathrm{C}$ ratio of 0.3 by weight (DiTullio \& Laws 1983). It is additionally necessary to assume that the allocation to protein over the incubation period is an accurate measure of the actual rate of protein synthesis, which would appear reasonable for long (24 h) incubations with cold-water populations as employed here (Li \& Harrison 1982).

\section{RESULTS}

\section{Spatial observations}

Like previous work in the NEW, the 1993 expedition revealed substantial spatial and temporal variability in phytoplankton and many chemical variables, of which the selected stations shown here give only a partial impression. Chl a concentrations varied widely among stations, both as column-integrated and surface values (e.g. Fig. 1). Even within the relatively circumscribed area of the time series stations, chl $a$ at the surface varied from $<0.1$ to $>1.0 \mathrm{mg} \mathrm{m}^{-3}$. Primary production was similarly variable (Fig. 1). High values of chl a and primary production were most commonly encountered in the central polynya region, as delimited by the time series area.

Allocation to macromolecules, particularly to protein and lipid (Fig. 2), was also variable among stations (Fig. 2), even within relatively small areas. Averaged over all 22 stations, the predominant macromolecular classes were protein and polysaccharide with lesser allocation to lipid and LMW (Table 1). The allocation to protein increased and that to polysaccharide and LMW decreased as depth increased. Primary production at the $0.1 \%$ light level was very low, so that events at the 5 and $100 \%$ levels were far more important in determining the column-integrated products of photosynthesis.

The average allocation to the major lipid classes, as a percent of total lipid, revealed a predominance of 

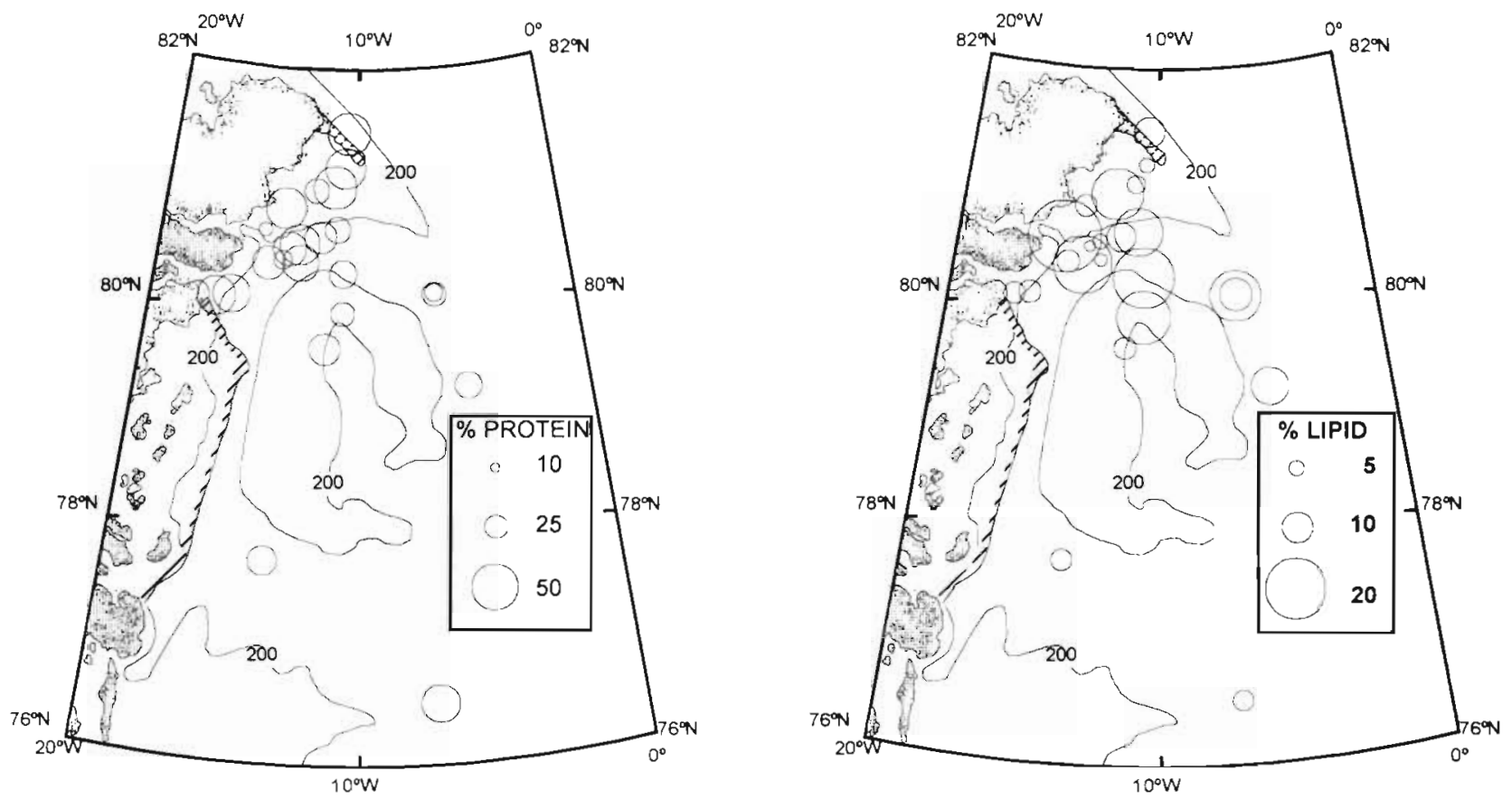

Fig. 2. Percent of total photosynthate directed to protein and to lipid in surface samples in and near the Northeast Water Polynya in summer 1993

glycolipids (including photosynthetic pigments) at the 5 and $100 \%$ depths (Table 1 ). The pattern at the $0.1 \%$ optical depth was by contrast dominated by phospholipids, with a substantial allocation to neutral lipids as well (Table 1). As for macromolecular allocation, the lipid class allocation patterns were also highly variable among stations and over time. Both for lipid class and macromolecular allocation, the variation among stations was far larger than the analytical and experimental error (see 'Materials and methods').

The grand averages in Table 1 collapse together results from stations that obviously differed widely in biological and physico-chemical characteristics. Aver-

Table 1. Average allocation to macromolecules in the Northeast Water (NEW) Polynya at optical depths of 100,5 and $0.1 \%$ as percent $( \pm S D$ ) of total photosynthate [low molecular weight metabolites (LMW), protein, polysaccharide and total lipids] or of total lipids (neutral lipids, glycolipids, phospholipids)

\begin{tabular}{|llll|}
\hline Variable & \multicolumn{1}{c}{$100 \%$} & $5 \%$ & $0.1 \%$ \\
\hline LMW & $16.0 \pm 8.6$ & $13.4 \pm 7.3$ & $12.2 \pm 9.0$ \\
Protein & $34.4 \pm 10.4$ & $41.5 \pm 8.8$ & $45.3 \pm 10.9$ \\
Polysaccharide & $38.8 \pm 7.5$ & $36.4 \pm 8.2$ & $31.8 \pm 5.8$ \\
Total lipids & $11.1 \pm 6.5$ & $10.5 \pm 7.9$ & $10.7 \pm 6.2$ \\
Neutral lipids & $13.3 \pm 10.4$ & $13.2 \pm 8.2$ & $19.7 \pm 5.1$ \\
Glycolipids & $63.5 \pm 34.7$ & $59.1 \pm 30.2$ & $26.3 \pm 4.8$ \\
Phospholipids & $21.6 \pm 18.8$ & $26.3 \pm 22.4$ & $51.1 \pm 6.8$ \\
\hline
\end{tabular}

ages pertaining to the 3 biologically defined production regimes (see 'Materials and methods') may be more interpretable (Table 2). The most noticeable differences were between the low biomass, flagellatedominated stations in Regime 5 and the diatom-dominated stations in Regimes 1 and 2. Among the macromolecular classes, relative allocation to LMW was less in Regime 5 than in the other regimes. Within the lipid pool, Regime 5 supported relatively greater allocation to neutral lipids and phospholipids, with much less allocation to glycolipids. Differences between Regimes 1 and 2 were comparatively minor. In the subset of stations analyzed here, the average nutrient concentrations were not strongly variable among regimes, although nitrate and silicate were depleted in Regime 2 versus Regimes 1 and 5. Despite the lower available nutrient concentrations in Regime 2, there was no significant difference among regimes in relative allocation to protein, polysaccharides or total lipids.

\section{Time series observations}

To gain some idea of the temporal component of the variability, we analyzed the course of events within the time series area (Fig. 3). Because of circulation through the area the results cannot be viewed strictly as the outcome of in situ processes within the time series area 
Table 2. Mean \pm SD for photosynthate allocation and some environmental and biological variables for surface samples (100\% optical depth) in 3 production regimes within the NEW Polynya region. Allocation to LMW protein, polysaccharide and total lipids as percent of total photosynthate. Allocation to neutral lipids, glycolipids and phospholipids as percent of total lipids synthesized. - Significant $(p<0.05)$ differences among regimes by Kruskal-Wallis test

\begin{tabular}{|c|c|c|c|}
\hline Variable & $\begin{array}{c}\text { Regime } 1 \\
\quad(\mathrm{n}=9)\end{array}$ & $\begin{array}{c}\text { Regime } 2 \\
(\mathrm{n}=10)\end{array}$ & $\begin{array}{c}\text { Regime } 5 \\
(n=4)\end{array}$ \\
\hline LMW & $19.3 \pm 8.9$ & $16.9 \pm 8.5$ & $8.7 \pm 3.6$ \\
\hline Protein & $33.7 \pm 9.6$ & $31.3 \pm 9.6$ & $38.4 \pm 6.3$ \\
\hline Polysaccharide & $36.3 \pm 5.8$ & $38.4 \pm 7.1$ & $45.2 \pm 10.1$ \\
\hline Total lipids & $10.6 \pm 7.6$ & $12.5 \pm 6.7$ & $7.6 \pm 1.4$ \\
\hline Neutral lipids ${ }^{*}$ & $12.1 \pm 6.6$ & $12.6 \pm 14.0$ & $21.1 \pm 3.7$ \\
\hline Glycolipids " & $67.5 \pm 25.8$ & $69.8 \pm 19.5$ & $23.2 \pm 0.7$ \\
\hline Phospholipids * & $17.8 \pm 23.0$ & $15.3 \pm 17.1$ & $50.9 \pm 2.3$ \\
\hline Protein:LMW & $2.3 \pm 1.6$ & $2.5 \pm 1.8$ & $4.8 \pm 1.8$ \\
\hline Protein:lipid & $4.4 \pm 2.9$ & $4.2 \pm 3.7$ & $5.1 \pm 0.7$ \\
\hline Surface nitrate $(\mu M)^{\bullet}$ & $2.0 \pm 1.4$ & $0.8 \pm 1.1$ & $3.5 \pm 1.2$ \\
\hline Surface silicate $\left(\mu^{\prime}\right)^{\circ}$ & $7.4 \pm 3.9$ & $5.6 \pm 4.1$ & $10.6 \pm 1.3$ \\
\hline Chlorophyll ( $\left.\mathrm{mg} \mathrm{m}^{-3}\right)^{\cdot}$ & $0.55 \pm 0.37$ & $0.70 \pm 0.48$ & $0.20 \pm 0.09$ \\
\hline Primary production ( $\mathrm{mg} \mathrm{C} \mathrm{m}^{-3} \mathrm{~d}^{-1}$ ) & $54.1 \pm 39.9$ & $48.2 \pm 47.9$ & $18.0 \pm 12.3$ \\
\hline Water temperature $\left({ }^{\circ} \mathrm{C}\right)^{\circ}$ & $0.4 \pm 2.1$ & $0.7 \pm 1.6$ & $-1.1 \pm 0.5$ \\
\hline
\end{tabular}

Allocation to LMW and total lipid varied inversely to protein (Fig. $4 \mathrm{a}$ ). $\mathrm{C} / \mathrm{N}$ assimilation ratios, calculated from the measured protein synthesis, reached a maximum of 18 (by weight) as nutrients reached their minimum concentrations, and subsequently decreased (Fig. 4b). Except for the first value in the series, the $\mathrm{C} / \mathrm{N}$ composition ratio followed a similar temporal trend but did not reach values $>9$ during the time series. Interestingly, the $\mathrm{C} / \mathrm{N}$ assimilation ratio was lower than the composition ratio at the beginning and end of the time series (Fig. 4b).

Allocation to neutral lipids increased during the period of depleted nutrients and decreased sharply as nutrient concentrations recovered (Figs. 3a \& 4c). Allocation to glycolipids increased from early to late in the time series, with a localized peak coincident with depietiun of the nuinitnis, while dilu-

but they do provide a useful picture of the variability with time within the NEW Dissolved nitrate+nitrite and silicate concentrations in samples from $<5 \mathrm{~m}$ depth decreased to a minimum in mid-July and subsequently increased again (Fig. 3a). Dissolved ammonium concentrations (not shown) varied over a small range, from 0.3 to $0.55 \mu \mathrm{M}$, with little systematic trend evident. Chl a concentrations increased early in the time series and remained high through most of the observation period, reaching their peak as nutrient depletion intensified, and then subsequently declined (Fig. 3b). Primary production rates were highly variable (Fig. 3b), due in part to variations in daily irradiance. An early peak in primary production coincided with a transitory reduction of silicate, but not nitrate, concentration. Later in the time series, the period of depleted nutrient concentrations was associated with variable but, on average, high rates of primary production. The time series of POC and PON in the surface waters (Fig. 3c) suggested an early and transitory accumulation of biomass with a second and larger peak coinciding with the onset of nutrient depletion.

There were pronounced variations in allocation to macromolecules and lipid classes during the time series (Fig. 4a, b). For clarity of presentation we have not shown error bars on the plots but the major variations alluded to here were outside the range of analytical and experimental errors (cf. coefficients of variation in 'Materials and methods'). Allocation to protein was maximal at the beginning and end of the time series, and reached its minimum as nitrate and silicate reached their lowest concentrations (Figs. 3a \& 4a). cation to phospholipids followed a roughly inverse pattern of variation to this (Fig. 4c).

The time series of events at the $5 \%$ light level was not as clearly resolved because of limited sampling. The nutrient data were quite complete, however, and revealed no sustained or severe nutrient depletion $\left(\mathrm{NO}_{3}+\mathrm{NO}_{2}>1 \mu \mathrm{M}\right.$ and silicate $>7 \mu \mathrm{M}$ throughout the sampling period). The biomass (chl $a$, POC, PON) and primary production rates at the $5 \%$ light level suggested 2 peaks corresponding to those seen at $100 \%$. The limited sampling for biosynthetic patterns at $5 \%$ (only 6 time points) did not reveal any variations coincident with those of production.

\section{Environmental correlates of macromolecular and lipid class allocation}

Correlation analysis was used to test for relationships between biosynthetic patterns and the variables water temperature, daily PAR irradiance, \% ice cover, chl a concentration, primary production rate (volumetric). and dissolved inorganic nutrient concentrations using the data from all 22 stations. At a significance level of $p=0.05$, allocation to protein was correlated only with silicate and nitrate+ nitrite concentrations, while allocation to polysaccharide was correlated only with temperature. Allocation to total lipid and LMW was inversely correlated with silicate and nitrate+nitrite but positively correlated with temperature.

The best forecasting models were then defined by regression analysis, using forward elimination to sys- 

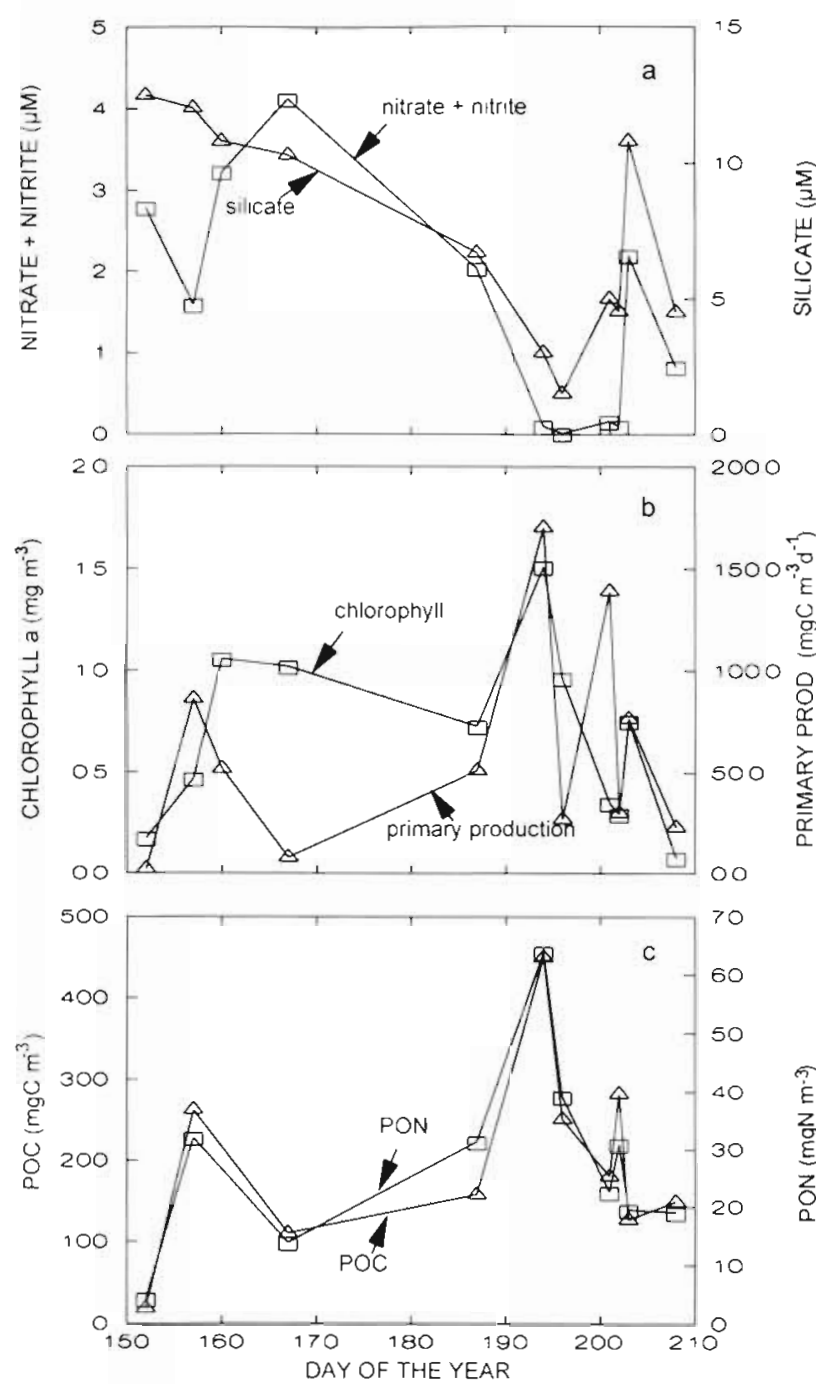

Fig. 3. Time course of (a) nitrate+nitrite and silicate, (b) chl a and primary production, and (c) particulate organic carbon and nitrogen (POC and PON) in surface samples within the time series area

tematically explore models with up to 2 predictor variables. Silicate emerged as the best predictor of allocation to protein and total lipids (Fig. 5a, Table 3). Nitrate+nitrite was the next best predictor but with substantially lower $\mathrm{R}^{2}$ of $33 \%$ for protein and $38 \%$ for total lipids. No model with 2 predictor variables was a significant improvement over the model with silicate alone for either protein or total lipids, according to $\mathrm{R}^{2}$ values and partial $F$-tests. With a few exceptions, the data for the $5 \%$ depth fell in the higher nutrient range and lay fairly close to the model line for the $100 \%$ optical depth (Fig. 5a). The major exceptions were 2 stations at which silicate was depleted but protein allocation at $5 \%$ was relatively high. The silicate model could in fact be fitted with high significance to the
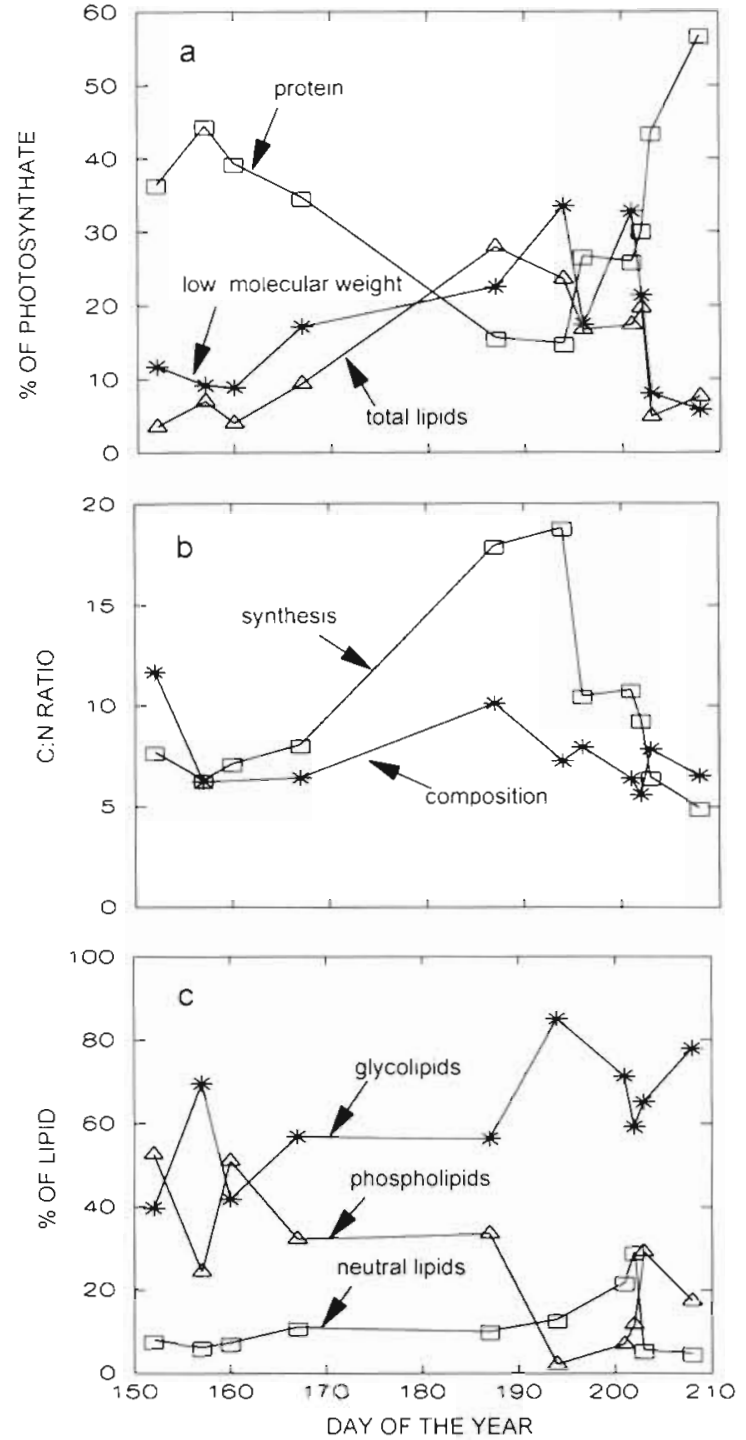

Fig. 4. Time course of (a) allocation to protein, LMW and total lipids as percent of total photosynthate, (b) C/N ratios (by weight) of assimilation and composition, and (c) allocation to glycolipids, phospholipids and neutral lipids as percent of

total lipid in surface samples within the time senes area

pooled 5 and $100 \%$ data for both protein and total lipid (Table 3), and no alternative model with 1 or 2 predictor variables was as successful.

Allocation to LMW was best fitted by a multiple regression model using silicate and primary production rate as predictors, while allocation to polysaccharide was best fitted by water temperature alone (Table 3). For polysaccharide, the model performed poorly when the data from $5 \%$ and $100 \%$ depths were pooled

The allocation ratios protein:LMW and protein:lipid were most closely related to silicate concentrations (Fig. 5b, c, Table 3). $\mathrm{R}^{2}$ values were lower for the 

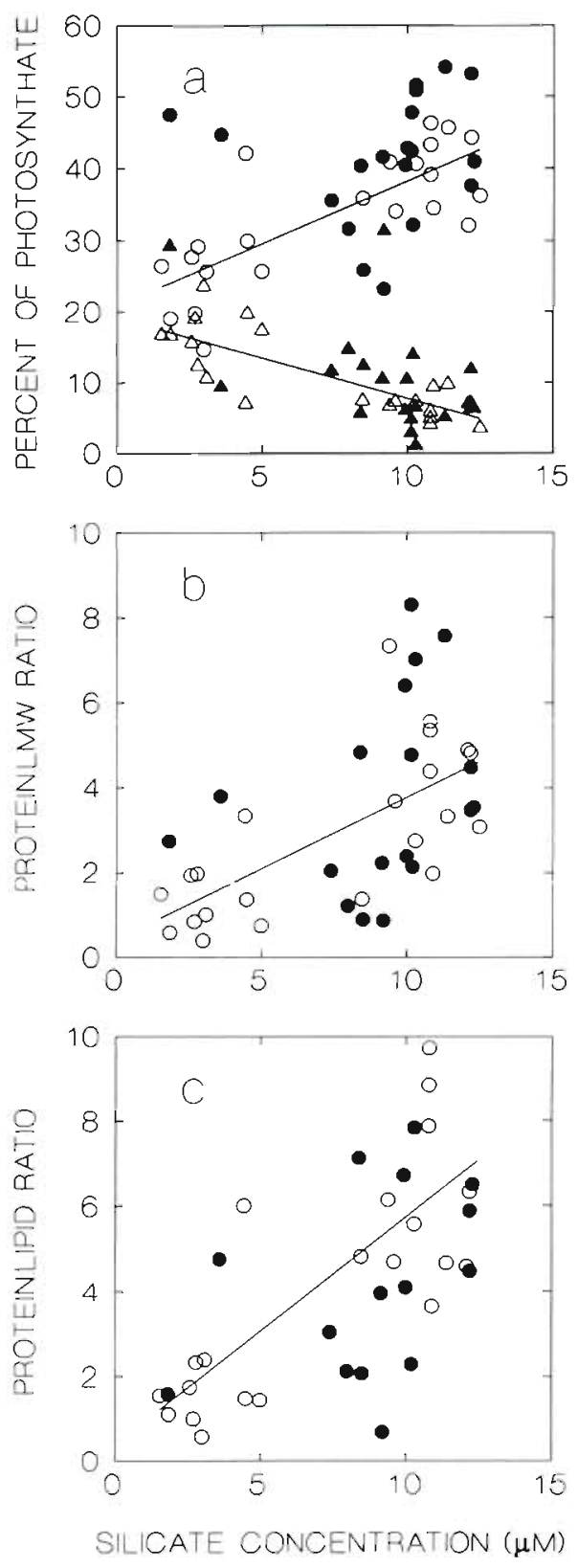

Fig. 5. Scatter plots illustrating the relationships between (a) photosynthate allocation to protein $(\bullet, 0)$ and total lipids ( $\Delta, \Delta$ ), (b) the protein:LMW allocation ratio, and (c) the protein:total lipids allocation ratio and soluble reactive silicate in samples from the $100 \%$ light level (open symbols) and the $5 \%$ light level (filled symbols) The lines shown were fitted by linear regression to the $100 \%$ light level data only (Table 3)

pooled data from 5 and 100\% depths than for the $100 \%$ alone, but were nonetheless highly significant $(\mathrm{p}<0.001)$.

Correlation analysis of allocation to lipid classes (as percent of total lipid allocation) showed that neutral lipids were correlated primarily (and inversely) with

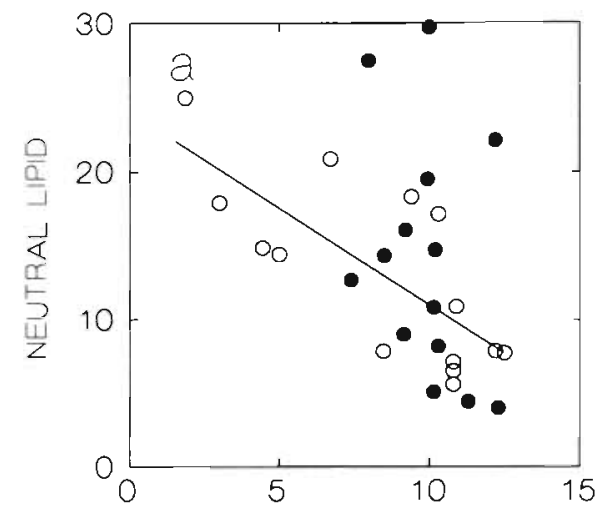

SILICATE CONCENTRATION $(\mu \mathrm{M})$

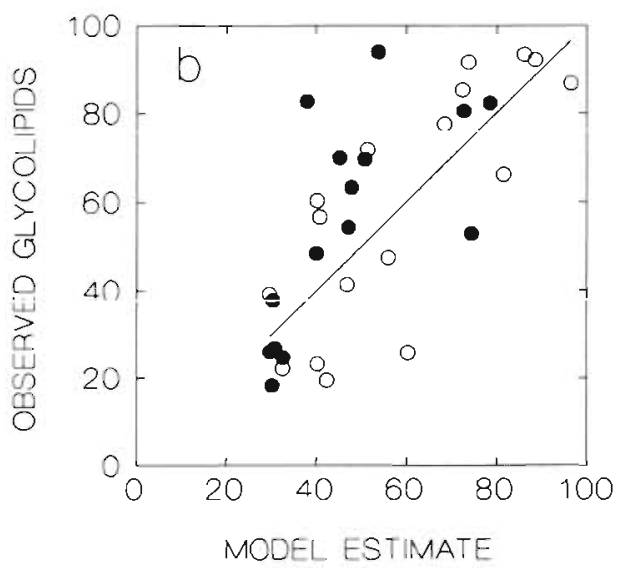

Fig. 6. Scatter plots illustra:ing the relationship between allocation to lipid classes (as percent of total lipid) and environmental factors with lines fitted by linear regression to surface (100\% light level) samples (Table 3). (a) Allocation to neutral lipid versus soluble reactive silicate concentration. (b) Allocation to glycolipids versus the value predicted from the fitted multivariate relationship. Open symbols: surface samples $(100 \%$ light level), filled symbols: samples from the $5 \%$ light level

silicate concentrations and weakly (and positively) with chl $a$ and primary production rates. Allocation to glycolipids and phospholipids was correlated primarily with temperature, primary production and chl $a$. The best regression model for neutral lipids was based on silicate concentration alone (Fig. 6a) but had relatively low $\mathrm{R}^{2}$ values (Table 3 ). Allocation to glycolipids was best fitted by a multiple regression model using temperature and total primary production rate as independent variables (Fig. 6b, Table 3) while allocation to phospholipids was best predicted by temperature (Table 3). Models using chl a instead of primary production were almost equally successful for both glycolipids and phospholipids. Whereas the allocation to glycolipids varied positively with temperature and with our measures of phytoplankton abundance and 
Table 3. Regression models for allocation of photosynthate to protein (PRO), total lipids (LIP), low molecular weight material (LMW), polysaccharides (POLY), neutral lipids (NL), glycolipids (GL), phospholipids (PL), the ratios of protein:LMW (PRO:LMW) and protein:lipids (PRO:LIP) for data at 100\% light level and pooled data of 100 and $5 \%$ light levels. Si: dissolved reactive silicate $(\mu M)$; PP: chlorophyll-specific primary productionrate ( $\mathrm{mg} \mathrm{C} \mathrm{mg}^{-1} \mathrm{chl} \mathrm{a}^{-1} \mathrm{~h}^{-1}$ ): Temp.: water temperature $\left({ }^{\circ} \mathrm{C}\right)$

\begin{tabular}{|c|c|c|}
\hline Model & $\mathrm{R}^{2}$ & n \\
\hline \multicolumn{3}{|l|}{$100 \%$ depth } \\
\hline$\% \mathrm{PRO}=21.7+1.7(\mathrm{Si})$ & 55 & 22 \\
\hline$\% L I P=18.7-1.1(\mathrm{Si})$ & 59 & 22 \\
\hline$\%$ LMW $=18.5-0.95(\mathrm{~S} 1)+0.099(\mathrm{PP})$ & 48 & 22 \\
\hline$\%$ POLY $=39.5-2.8($ Temp. $)$ & 40 & 22 \\
\hline $\mathrm{PRO}: \mathrm{LMW}=0.41+0.34(\mathrm{Si})$ & 57 & 22 \\
\hline PRO:LIP $=0.19+0.58(\mathrm{Si})$ & 62 & 22 \\
\hline$\% \mathrm{NL}=28.9-1.5(\mathrm{Si})$ & 25 & 17 \\
\hline$\% \mathrm{GL}=49.2+12.4($ Temp $)+0.35(\mathrm{PP})$ & 57 & 17 \\
\hline$\% \mathrm{PL}=21.8-12.2$ (Temp.) & 43 & 17 \\
\hline \multicolumn{3}{|l|}{$100 \%+5 \%$ depth } \\
\hline$\% \mathrm{PRO}=18.8+2.1(\mathrm{Si})$ & 51 & 40 \\
\hline$\%$ LIP $=19.8-1.2(\mathrm{Si})$ & 50 & 40 \\
\hline$\% L M W=18.5-0.92(\mathrm{Si})+0.091(\mathrm{PP})$ & 44 & 40 \\
\hline$\%$ POLY $=38.2-1.4$ (Temp.) & 13 & 40 \\
\hline PRO:LMW $=0.45+0.37(\mathrm{Si})$ & 37 & 40 \\
\hline PRO:LIP $=0.32+0.57(\mathrm{Si})$ & 42 & 40 \\
\hline$\% \mathrm{NL}=24.1-1.3(\mathrm{Si})$ & 20 & 32 \\
\hline$\% G L=54.7+11.8($ Temp. $)+0.31(P P)$ & 49 & 32 \\
\hline$\% \mathrm{PL}=30.4-9.1$ (Temp.) & 42 & 32 \\
\hline
\end{tabular}

productivity (chl a and primary production rate), the allocation to phosopholipids varied inversely (Table 3).

When regression analysis of macromolecular and lipid class allocation was restricted to the diatom-dominated stations (Regimes 1 and 2) similar results were obtained. The flagellate-dominated stations, although apparently different in many respects from the diatomdominated stations (Table 2), were evidently too few in number to exert undue influence in the regression analyses. The relationships therefore represent events among stations of broadly similar (diatom-dominated) species composition.

\section{DISCUSSION}

Previous work on the NEW has led to the understanding that the origin of reduced ice cover in the polynya lies basically in the combined presence of a fast ice barrier near $79^{\circ} \mathrm{N}$ (the Norske Øer barrier), extending perpendicular from the coast, and a northward-flowing coastal current (the North East Greenland Coastal Current) such that ice advected out of the polynya is not replaced except by in situ growth (Schneider \& Budéus 1994, 1995). Phytoplankton blooms ensue in the polynya when melt waters and heat input produce stable stratification. The principal source of nutrients for phytoplankton is thought to be the East Greenland Shelf Water that flows northward into the polynya emerging north of the ice barrier (Lara et al. 1994). The low concentration of nitrate in the Polar Water and its depletion by phytoplankton growth in the polynya have been interpreted to mean that phytoplankton blooms in the NEW Polynya are ultimately N-limited (Lara et al. 1994, Smith 1995, W O. Smith et al. 1995, 1996). Our results support the conclusion that phytoplankton are at times nutrientlimited in the NEW, but they also point to silicon as a limiting nutrient at some stations.

According to several studies (e.g. Morris 1981, DiTullio \& Laws 1983, 1986, Smith \& Geider 1985), the proportion of photosynthate directed to protein is maximal (commonly 40 to $55 \%$ ) in nutrient-sufficient microalgae and decreases as growth limitation by nutrients intensifies. If applied to our results in the NEW, this would suggest that the phytoplankton were nutrient sufficient, or nearly so, except where significant depletion of silicate and nitrate was observed. The protein:LMW allocation ratio, another index of seemingly broad applicability (Madariaga \& Fernández 1990. Madariaga et al. 1991. Madariaga 1992), was also consistent with some nutrient limitation of growth rates when silicate and nitrate were depleted. Physiological evidence of nutrient limitation was observed almost exclusively in the surface (100\% optical depth) samples, with few signs of nutrient stress in samples from the $5 \%$ optical depth. On average, the phytoplankton allocated more photosynthate to protein and less to polysaccharide and LMW at the 5 and $0.1 \%$ depths than at the $100 \%$ depth, consistent with previous studies of allocation under light limitation (e.g. Morris 1981, Smith \& Geider 1985, Smith et al, 1987). However, the apparent effect of light may be due more to the fact that low nutrient concentrations were more frequent for the $100 \%$ than the 5 or $0.1 \%$ depths (Fig. 5). The development of deep chlorophyll maxima in areas of depleted surface nutrients in the NEW (Lara et al. 1994, Smith et al. 1995) can thus be understood to result at least in part from differential nutrient availability and growth with depth, and not solely from the interaction of sinking rates and density fields.

Both the correlation analyses and the time series approach indicated that allocation shifted away from protein and towards lipid and LMW material, but not polysaccharide, when nutrients were depleted. Increased allocation to lipid has been reported for diatoms grown into nitrogen and, especially, silicon limitation (Shifrin \& Chisholm 1981, Parrish \& Wangersky 1987, Madariaga 1992, R. E. H. Smith et al. 1996). The responses observed in the NEW were therefore 
consistent with the predominance of diatoms at stations where phytoplankton biomass was high and nutrients depleted (Pesant et al. 1996). When lipid synthesis is stimulated by nutrient deficiency, it is normally expected that neutral lipids will be preferentially synthesized, since they comprise the principal class of storage molecules (Parrish \& Wangersky 1987, Gurr \& Harwood 1991). There was in fact a shift in lipid class allocation toward neutral lipids corresponding with nutrient depletion and increased total lipid synthesis, further suggesting that the changing patterns of macromolecular and lipid class allocation were indeed responses to physiological nutrient deficiency.

Dugdale et al. (1995) have argued that in nitrogenrich upwelling regions, silicon is the nutrient that effectively controls export production because of its negligible surface regeneration rates and importance to diatoms, which are the main component of the vertical flux of algal biomass. The NEW is not a N-rich area (Lara et al. 1994) but diatoms are abundant (Lara et al. 1994, Smith et al. 1995, Pesant et al. 1996) and our results suggest that silicon may play an important role in iimiting didtom growth in the poiynyd. In the time series, the macromolecular allocation patterns varied more closely with silicate than nitrate. Specifically, recovery of physiological indicators such as percent allocation to protein and the protein:LMW ratio occurred when silicate recovered to $4 \mu \mathrm{M}$ or more but while nitrate+nitrite were still strongly depleted (Figs. 3 \& 4) and ammonium remained at its previous level. The same physiological indicators were also much better correlated with silicate than with nitrate+nitrite (even though silicate and nitrate were well correlated) according to the regression analyses. Silicon is not directly involved as a catalyst or substrate for synthesis of lipids or proteins, but silicon deficiency is an effective stimulus for increased lipid synthesis and decreased protein synthesis in diatoms (Taguchi et al. 1987).

The lower silicate concentrations observed in the NEW would not be strongly limiting to many marine diatoms studied in culture to date (Stapleford \& Smith 1996). However, they would be near or below the halfsaturation constant for uptake and/or growth by diatoms in the Peru Current Upwelling System (Dugdale et al. 1995) and in some areas of the Southern Ocean (Sommer 1986). It is quite possible, then, that the biomass-dominant phytoplankton at the bloom stations (diatoms) were more limited by silicon than nitrogen even though the total phytoplankton assemblage succeeded in depleting the nitrate+nitrite to very low concentrations (and thus coming to depend largely on ammonium regenerated in the surface mixed layer). Unfortunately there are no measurements of silicate utilization kinetics in or near the NEW to test the possibility of silicon limitation more rigorously.
It has been noted previously that polar phytoplankton tend to have $\mathrm{C} / \mathrm{N}$ assimilation ratios higher than expected for balanced growth when measured using ${ }^{15} \mathrm{~N}$ and ${ }^{14} \mathrm{C}$ (Smith \& Harrison 1991). Since parallel values for the $\mathrm{C} / \mathrm{N}$ composition ratio of the seston tend to be lower it has been suggested that there may be some additional $\mathrm{N}$ assimilation that is not registered in the usual tracer measurements or the excess $C$ may be lost from particulate form (Smith \& Harrison 1991). The $\mathrm{C} / \mathrm{N}$ composition ratios themselves tend to values higher than the balanced Redfield ratio in NEW, both in 1992 (Smith et al. 1995) and 1993 (present study), and relatively low ratios of $\mathrm{chl} a$ to POC and PON have been noted in both years. Such observations may indicate a major contribution of detritus and/or the variable influences of light and nutrient conditions in the polynya (Smith et al. 1995).

The time series analyzed here indicated that phytoplankton $\mathrm{C} / \mathrm{N}$ assimilation ratios in the NEW, as inferred from protein allocation, were only slightly above balanced values until nutrients were depleted, when they become far larger. If we include all our sta-

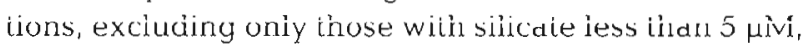
then the $\mathrm{C} / \mathrm{N}$ assimilation ratio from protein labelling averaged $6.9 \pm 1.6(\mathrm{SD} ; \mathrm{n}=32$ ) compared to the expected (Redfield) value of 5.7 for balanced growth. The average $\mathrm{C} / \mathrm{N}$ ratio of the seston for the same stations was almost identical, $7.1 \pm 2.0(\mathrm{SD} ; \mathrm{n}=27)$. The average $\mathrm{C} / \mathrm{N}$ assimilation ratio for all stations, including those with silicate $<5 \mu \mathrm{M}$, was $8.4 \pm 4.0$, and the ratio averaged $11.6 \pm 3.6$ for stations with silicate $<5 \mu \mathrm{M}$. Seston composition ratios were by comparison $7.3 \pm 3.2$ for all stations and $7.9 \pm 1.1$ for silicatedepleted stations. These results suggest that nutrient limitation, specifically by silicate, was a contributing factor in the relatively high $\mathrm{C} / \mathrm{N}$ assimilation ratios of phytoplankton in the NEW, and that there was no disparity between assimilation and composition ratios when silicate was present in adequate concentrations. This would support the suggestion that high $\mathrm{C} / \mathrm{N}$ seston composition ratios observed in the NEW in 1992 were related to nutrient depletion (Smith et al. 1995). Seston composition ratios apparently responded to nutrient depletion during our study in 1993, but not as strongly as the assimilation ratios, which may in part reflect the rapid sinking of silicate-limited diatoms and thus their removal from the particulate material of the surface layer.

The biological regimes defined by Pesant et al. (1996) presented a significant contrast between relatively sparse populations of small $(<5 \mu \mathrm{m}$ nominal dimension), mainly flagellate phytoplankton under nutrient-sufficient but low irradiance conditions (Regime 5) and relatively dense populations of large, mainly diatom phytoplankton under relatively high 
irradiance but lower nutrient availability (Regime 1 and, especially, 2). The flagellates in the NEW were Phaeocystis (unicellular form), dinoflagellates, and unidentified taxa. Some marine flagellates (including Phaeocyctis) and/or flagellate-dominated communities can show relatively more allocation of carbon to lipids and less to protein than usually observed in other algal groups, including diatoms (Madariaga 1992, Fernández et al. 1992, 1994a). However, the flagellate-dominated Regime 5 in the NEW did not differ significantly from the other regimes in relative allocation to protein or total lipids. The proportion of the lipids allocated to the neutral class was significantly higher for Regime 5 , however, reminiscent of the pattern seen in the coccolithophorid Emiliania huxleyi (Fernández et al. 1994b), and allocation to glycolipids was much less. The relatively large differences in lipid class allocation are not obviously explicable in terms of environmental influences, which should have favoured relatively little neutral lipids and much glycolipids under the nutrientsufficient but low irradiance conditions in Regime 5, and would appear instead to be examples of taxonomic influences on allocation patterns.

Predicting photosynthate allocation from environmental factors in the NEW, as has previously been attempted in fresh waters (Cuhel \& Lean 1987, Lean et al. 1989, Wainmann \& Lean 1992), does not appear very promising based on the present results. Even the most successful models had $\mathrm{R}^{2}$ values less than $60 \%$ and the data often tended towards a discontinuous distribution in the dependent and/or predictor variable (e.g. protein and lipid vs silicate; Fig. 5a). Concerning lipid, it should in theory be possible to attain relatively good predictions from environmental factors if the lipid is separated into classes of relatively homogeneous function (Gurr \& Harwood 1991). However, the lipid classes (neutral lipids, glycolipids, and phospholipids) proved to be no more easily estimated than total lipid itself. This may reflect taxonomic influences, as discussed above, but regression analyses confined to the diatom-dominated stations were no more successful. Nonetheless, the regression analyses did show that $\mathrm{Si}$, not $N$, was the environmental variable most closely related to protein and total lipid synthesis. Furthermore, the various lipid classes followed distinct relationships with the predictor variables, consistent with the idea that they differ in their functional roles. A better predictive understanding of biosynthetic patterns may emerge as further studies of the differences among major algal groups (e.g. Fernández et al. 1992, Madariaga 1992) become available.

Acnowledgements. This research was supported by grants from the Natural Sciences and Engineering Research Council of Canada, Fonds FCAR of Quebec, and Fonds Institutionel de Recherche, Université du Québec à Rimouski. Thanks to the masters and crew of RV 'Polarstern', the nutrient group of the Alfred Wegener Institute onboard 'Polarstern' and our technical assistants, G. Bergeron, K. Daly, C. Fraikın, R. J Lara, S. Lessard, F. McGuiness and C. Belzile. This is contribution number 1189 of the Alfred Wegener Institute for Polar and Marine Research.

\section{LITERATURE CITED}

Cuhel RL, Lean DRS (1987) Influence of light intensity, light quality, temperature and daylength on uptake and assimilation of carbon dioxide and sulfate by lake plankton. Can J Fish Aquat Sci 44:2118-2132

DiTullio GR, Laws EA (1983) Estimates of phytoplankton N uptake based on ${ }^{14} \mathrm{CO}_{2}$ incorporation into protein. Limnol Oceanogr 28:177-185

DiTullio GR, Laws EA (1986) Diel perıdicity of nitrogen and carbon assimilation in five species of marine phytoplankton: accuracy of methodology for predicting $N$ assimilation rates and $\mathrm{N} / \mathrm{C}$ assimilation ratios. Mar Ecol Prog Ser 32: $123-132$

Draper N, Smith H (1966) Applied regression analysis. John Wiley \& Sons, New York

Dugdale RC, Wilkerson FP, Minas HJ (1995) The role of a silicate pump in driving new production. Deep Sea Res 42 : $697-719$

Fernández E, Balch WM, Maranón E, Holligan PM (1994b) High rates of lipid biosynthesis in cultured, mesocosm and coastal populations of the coccolithophore Emiliania huxleyi. Mar Ecol Prog Ser 114:13-22

Fernández E, Maranón E, Harbour DS, Pingree RD (1994a) Phytoplankton carbon incorporation patterns and biochemical composition of particulate matter in the eastern North Atlantic subtropical region. J Plankton Res 16: $1627-1644$

Fernández E, Serret P, Madariaga I, Harbour DS, Davies AG (1992) Photosynthetic carbon metabolism and biochemical composition of spring phytoplankton assemblages enclosed in microcosms: the diatom-Phaeocystis sp. succession. Mar Ecol Prog Ser 90:89-102

Gurr MI, Harwood JL (1991) Lipid biochemistry. Chapman \& Hall, New York

Hitchcock GL (1983) Photosynthate partitioning in cultured marine phytoplankton 1. Dinoflagellates. J Exp Mar Biol Ecol 69:21-36

Kattner G, Becker H (1991) Nutrients and organic nitrogenous compounds in the marginal ice zone of the Fram Strait. J Mar Sys 2:385-394

Kattner G, Hirche HJ, Krause M (1989) Spatial variability in lipid composition of calanoid copepods from Fram Strait, the Arctic. Mar Biol 102:473-480

Lara RJ, Kattner G, Tillmann U, Hirche HJ (1994) The North East Water polynya (Greenland Sea). Il. Mechanisms of nutrient supply and influence on phytoplankton distribution. Polar Biol 14:483-490

Laws EA (1991) Photosynthetic quotients, new production and net community production in the open ocean. Deep Sea Res 38:143-167

Lean DRS, Cuhel RL, Charlton MN (1989) Protein synthesis: a measure of growth for lake plankton. Hydrobiologia 173: $119-126$

Legendre L, LeFère J (1991) From individual plankton cells to pelagic ecosystems and to global biogeochemical cycles In: Demers $\mathrm{S}$ (ed) Particle analysis in oceanography. Springer-Verlag, Berlin, p 261-300 
Li WKW, Glover HE, Morris I (1980) Physiology of carbon photoassimilation by Oscillatoria thiebautii in the Caribbean Sea. Limnol Oceanogr 25:447-456

Li WKW. Harrison WG (1982) Carbon flow into the end products of photosynthesis in short and long incubations of a natural phytoplankton population. Mar Biol 72:175-182

Madariaga I (1992) Interspecific differences in the photosynthetic carbon metabolism of marine phytoplankton. Mar Biol 114:509-515

Madariaga I, Fernández E (1990) Photosynthic carbon metabolism of size-fractionated phytoplankton during an experimental bloom in marine microcosms. J Mar Biol Ass UK 70:531-543

Madariaga I, Fernández E, Serret P (1991) Testing the validity of the synthesis ration of protein to low molecular weight metabolites as an estimation of phytoplankton growth in the field. J Mar Biol Ass UK 7 1:489-492

Madariaga I, Joint I (1992) A comparative study of phytoplankton physiological indicators. J Exp Mar Biol Ecol 158: $149-165$

Morris I (1981) Photosynthesis products, physiological state and phytoplankton growth. In: Platt I (ed) Physiological bases of phytoplankton ecology. Can Bull Fish Aquat Sci 210:83-102

Parrish CC (1987) Separation of aquatic lipid classes by chromarod thin-layer chromatography with measurement by Iatroscan flame ionization detection. Can J Fish Aquat Sci $44: 722-731$

Parrish CC, McKenzie CH, MacDonald BA, Hatfield EA (1995) Seasonal studies of seston lipids in relation to microplankton species composition and scallop growth in South Broad Cover, Newfoundland. Mar Ecol Prog Ser 129:151-164

Parrish CC, Wangersky PJ (1987) Particulate and dissolved lipid classes in cultures of Phaeodactylum tricornutum grown in cage culture turbidostats with a range of nitrogen supply rates. Mar Ecol Prog Ser 35:119-128

Parsons TR, Maita Y, Lalli CM (1984) A manual of chemical and biological methods for seawater analysis. Pergamon Press, Toronto

Pesant S, Legendre L, Gosselin M, Smith REH, Kattner G, Ramseier RO (1996) Size-differential regimes of phytoplankton production in the Northeast Water Polynya $\left(77^{\circ}\right.$ $81^{\circ}$ N). Mar Ecol Prog Ser 142:75-86

Rivkin RB (1985) Carbon-14 labelling patterns of individual marine phytoplankton from natural populations. Mar Bio] 89:135-142

This article was submitted to the edator
Schneider W, Budéus G (1994) The North East Water Polynya (Greenland Sea). I. A physical concept of its generation. Polar Biol 14:1-9

Schneider W, Budéus G (1995) On the generation of the Northeast Water Polynya. J Geophys Res 100:4269-4286

Shifrin NS, Chisholm SW (1981) Phytoplankton lipids: interspecific differences and effects of nitrate, silicate and light-dark cycles. J Phycol 17:374-384

Smith REH, Clement P, Cota GF, Li WKW (1987) Intracellular photosynthate allocation and the control of Arctic marine ice algal production. J Phycol 23:124-132

Smith REH, D'Souza FML (1993) Macromolecular labelling patterns and inorganic nutrient limitation of a North Atlantic spring bloom. Mar Ecol Prog Ser 92:111-118

Smith REH, Geider RJ (1985) Kınetics of intracellular carbon allocation in a marine diatom. J Exp Mar Biol Ecol 93: $191-210$

Smith REH, Gosselin M. Taguchi S (1996) The influence of major inorganic nutrients on the growth and physiology of high Arctic ice algae. J Mar Sys (in press)

Smith WO (1995) Primary productivity and new production in the Northeast Water (Greenland) Polynya during summer 1992. J Geophys Res 100:4357-4370

Smith WO, Gosselin M, Legendre L, Wallace DWR, Daly K Kattner $G$ (1996) New production in the Northeast Water Polynya: 1993. J Mar Sys (in press)

Smith WO, Harrison WG (1991) New production in polar regions: the role of environmental controls. Deep Sea Res 38:1463-1479

Smith WO, Walsh ID, Booth BC, Deming JW (1995) Particulate matter and phytoplankton and bacterial biomass distributions in the Northeast Water Polynya during summer 1992. J Geophys Res 100:4341-4356

Sommer U (1986) Nitrate and silicate competition among antarctic phytoplankton. Mar Biol 91:345-351

Stapleford LS, Smith REH (1996) The interactive effects of temperature and silicon limitation on the psychrophilic ice diatom, Pseudonitzschia seriata. Polar Biol 16 : $589-594$

Taguchi S, Hirata JA, Laws EA (1987) Silicate deficiency and lipid synthesis of marine diatoms. J Phycol 23:260-267

Wainmann BC, Lean DRS (1992) Carbon fixation into lipid in small freshwater lakes. Limnol Oceanogr 37:956-965

Wainmann BC, Lean DRS (1994) Methodological concerns in measuring the lipid fraction of carbon fixation. Hydrobiologia 273:111-120

Manuscript first received: July 12, 1996

Revised version accepted: November 26, 1996 